\title{
UTERINE CAPACITY IN GILTS
}

\author{
FULLER W. BAZER, A. J. GLAWSON, O. W. ROBISON \\ AND L. G. ULBERG \\ Department of Animal Science, North Carolina State University, \\ Raleigh, North Carolina, U.S.A.
}

(Received 17th June 1968, accepted 23rd September 1968)

A review of the literature indicates that injection of gonadotrophic hormones or giving high-level-energy feeds will markedly increase the number of ovulations in polytocous animals. Higher ovulation rates are then followed by an increase in the percentage of embryos which die in utero. This increased embryonic death may be due either to inherent limitations within the individual embryo or to maternal limitations which affect the litter (Runner, 1951). In any event, the number of young at term remains at a level characteristic for the species. Embryonic death usually occurs before the time of attachment of the embryo to the endometrium (Boyd, 1965).

Attempts to increase the number of young born either by hormonal superovulation (Fowler \& Edwards, 1957; Adams, 1960; Hafez, 1964) or by the addition of embryos to the uterine horns (McLaren \& Michie, 1959; Adams, 1960) have seldom been successful. In some experiences (Adams, 1960; Hafez, 1964) litter size was actually reduced. Exceptions to these general findings have been presented for mice (Sato, 1959; Wilson \& Edwards, 1963).

In view of this evidence, it was postulated that some uterine mechanism limits the number of embryos that may undergo implantation or placentation. This limit may be through a process of selection which favours development of the more viable embryos since they may be able to compete more successfully for some biochemical factor necessary in the key steps of embryonic development (Krishnan \& Daniel, 1967). This postulate is further enhanced by the observations that a reduction occurred in the number of fertilized ova which continued development when the blood supply to the uteri of mice was limited (Senger, Lose \& Ulberg, 1967). Reduction in blood flow to the ovarian onethird of the uterine horn was particularly detrimental to the embryo's survival. Critical periods of development occur in embryos of mice (2- to 4-cell stage), rabbits (morula to blastocyst stage) and swine (4-cell stage) grown in vitro (Cole, Edwards \& Paul, 1966; Whittingham, 1966; Elliott, personal communication). In each species, some factor in the female reproductive tract seems to be necessary for continued embryonic development.

Characteristic patterns of embryonic death in domestic swine (Sus scrofa domestica) are well documented in the literature. Most of the embryonic deaths occur during the first 25 days (Gossett \& Sorensen, 1959) of the 114-day gestation period. Therefore, this species was used in the present experiment to 
test the hypothesis that the uterus is responsible for limiting litter size at term.

Crossbred gilts, mated to boars with epistatically dominant genes for white hair colour, served as recipients. To evaluate the inherent fertility of these animals and to determine the effects of surgery on embryonic survival, intact and sham-operated animals served as controls (Table 1).

A group of primiparous Duroc sows provided genetically marked embryos, homozygous recessive for red hair. Transfer-pairs were formed for embryo transfer, by natural synchrony of onset of oestrus $( \pm 12 \mathrm{hr}$ ), between a mated gilt (white offspring) and a mated donor sow (red offspring). Embryo transfer was performed, as previously described (Vincent, Robison \& Ulberg, 1964), approximately $63 \pm 6 \mathrm{hr}$ after the donor animal was detected in oestrus. The number of corpora lutea in the ovaries of the recipient female was determined at the time of surgery. Each corpus luteum was assumed to represent one ovum and, consequently, one potential embryo genetically marked for white hair

TABLE 1

LITTER SIZE AFTER ADDITION (SUPERINDUGTION) OF EXTRA EMBRYOS

\begin{tabular}{|c|c|c|c|c|c|}
\hline \multirow{2}{*}{ Factor } & \multicolumn{5}{|c|}{ Treatment groups } \\
\hline & Control & Sham* & 16 & $\begin{array}{l}\text { otential embryos } \\
\quad 22\end{array}$ & 28 \\
\hline No. of gilts & 11 & 11 & 8 & 8 & 8 \\
\hline Ovulation rate, av. $\dagger$ & $11 \cdot 3$ & $10 \cdot 4$ & $11 \cdot 3$ & $12 \cdot 1$ & 13.5 \\
\hline No. embryos added, av. $\ddagger$ & 0.0 & 0.0 & $4 \cdot 7$ & $9 \cdot 9$ & $14 \cdot 5$ \\
\hline No. total embryos, av. & $11 \cdot 3$ & $10 \cdot 4$ & $16 \cdot 0$ & $22 \cdot 0$ & $28 \cdot 0$ \\
\hline Litter size, av. $\$ \pm$ S.E. & $\mathrm{g} .9 \pm 0.34$ & $8 \cdot 2 \pm 0 \cdot 50$ & $8.8 \pm 0.65$ & $8 \cdot 5 \pm 1 \cdot 13$ & $9.9 \pm 0.74$ \\
\hline Foetal wt, av. (g) & 671 & 666 & 679 & 599 & 575 \\
\hline
\end{tabular}

* Surgery without the addition of embryos.

$\uparrow$ Each ovulation point was assumed to represent an embryo genetically marked for white hair colour. Genetically marked for red hair colour.

$\$$ At 87 to 93 days of gestation.

colour (native embryo). Embryos genetically marked for red hair colour (foreign embryos) were then added to the uterine horns just below the tubouterine junction of the gilts so that the total number of potential embryos in each animal was either 16, 22 or 28 . Recipients were slaughtered at approximately 90 days of gestation and the parentage of each foetus was determined.

Average litter size at the time of slaughter was 8.8, 8.5 and 9.9 for the groups receiving 16, 22 or 28 potential embryos, respectively. These values did not differ significantly from each other nor did they differ from those obtained from the non-operated and sham-operated control gilts (9.9 and 8.2). Differences among treatments for foetal weight were not significant (Table 1). This indicates that the majority of embryo selection (embryo death) occurs early in gestation.

Besides limiting the size of the litter, the uterus selects those embryos which make up the litter. This is demonstrated by the differential selection of transferred embryos. Although embryos were not recovered from the gilts at the time 
of surgery, previous data indicated that at approximately $63 \mathrm{hr}$ after onset of oestrus there would be an average of 4.7 blastomeres per embryo in this type of female. Embryos from the donor sows had an actual average of 2.9 blastomeres per embryo in this experiment. Therefore, it appears that the sows ovulated later after onset of oestrus than did the gilts. Consequently, the stage of embryonic development was either approximately the same for the two types of embryos or the foreign embryos were 12 or $24 \mathrm{hr}$ behind the native embryos in development. Data on reproductive performance of the recipient animals are arranged according to degree of synchrony between members of a transfer pair (Table 2). These data demonstrate the need for proper synchrony between embryonic and uterine development. When foreign and native embryos were similar in development there was no significant difference in survival rates between the two kinds of embryos developing in a common uterus. However, a significant difference $(P<0.01)$ in survival did exist when development of foreign embryos was either 12 or $24 \mathrm{hr}$ behind that of the recipient's own embryos. Regardless of synchrony, essentially the same relative

TABLE 2

SURVIVAL RATE OF FOREIGN AND NATIVE EMBRYOS WHEN SYNCHRONY IN STAGE OF DEVELOPMENT OF THE FOREIGN EMBRYOS IS VARIED*

\begin{tabular}{|c|c|c|c|c|c|c|c|c|}
\hline \multirow{2}{*}{$\begin{array}{c}\text { Synchrony of } \dagger \\
\text { embryos }\end{array}$} & \multirow{2}{*}{$\begin{array}{l}\text { No. } \\
\text { recipient } \\
\text { gilts }\end{array}$} & \multicolumn{4}{|c|}{ Embryo survival } & \multirow{2}{*}{$\begin{array}{l}\text { Av. no. } \\
\text { potential } \\
\text { embryos }\end{array}$} & \multirow{2}{*}{$\begin{array}{c}\text { Av. no. } \\
\text { normal } \\
\text { foetuses } \\
\pm S . E .\end{array}$} & \multirow{2}{*}{$\begin{array}{l}\text { Per cent } \\
\text { overall } \\
\text { survival }\end{array}$} \\
\hline & & Native $\left({ }^{\circ}\right.$ & & Foreig & $(\%)$ & & & \\
\hline $\begin{array}{l}\text { Equal } \\
-12 \mathrm{hr} \\
-24 \mathrm{hr}\end{array}$ & $\begin{array}{r}7 \\
10 \\
7\end{array}$ & $\begin{array}{l}45 / 88 \\
74 / 131 \\
55 / 76\end{array}$ & $\begin{array}{l}51 \\
56 \\
72\end{array}$ & $\begin{array}{c}21 / 60 \\
20 / 101 \\
2 / 69\end{array}$ & $\begin{array}{l}35 \\
20^{* *} \\
3^{* *}\end{array}$ & $\begin{array}{l}21 \\
23 \\
21\end{array}$ & $\begin{array}{l}9.4 \pm 1.02 \\
9.4 \pm 0.85 \\
8.1 \pm 0.67\end{array}$ & $\begin{array}{l}45 \\
41 \\
39\end{array}$ \\
\hline
\end{tabular}

* Data pooled across treatments.

$\dagger$ Development of foreign relative to native embryos.

** Significantly $(P<0.01)$ less than the survival rate of the native embryo.

percentage of the potential embryos was selected, and survived, so that average litter size at term was similar among groups. Thus, increased death associated with increased embryo numbers appears to be due to maternal limitations and not due to inherent limitations of the embryo. This uterine mechanism acts to limit litter size to a level characteristic for the species. It seems apparent, therefore, that the barrier imposed by uterine capacity must be removed before a marked increase in reproductive rates of polytocous animals can be realized.

This research was supported in part by NIH grant HD 02923, from the National Institute of Child Health and Human Development.

\section{REFERENCES}

Adams, G. E. (1960) Prenatal mortality in the rabbit, Oryctolagus cuniculus. 7. Reprod. Fert. 1, 36. Boyd, H. (1965) Embryonic death in cattle, sheep and pigs. Vet. Bull. 35, 251.

Cole, R. J., Edwards, R. G. \& Paul, J. (1966) Cytodifferentiation and embryogenesis in cell colonies and tissue cultures derived from ova and blastocysts of the rabbit. Devl Biol. 13, 385. 
Fowler, R. E. \& EDWARds, R. G. (1957) Induction of superovulation and pregnancy in mature mice by gonadotrophins. Endocrinology, 15, 374 .

Gossett, J. W. \& Sorenson, A. M., JR (1959) A comparison of embryo survival in gilts slaughtered twenty-five versus forty days after breeding. F. Anim. Sci. 18, 48.

HAFEZ, E. S. E. (1964) Effects of over-crowding in utero on implantation and fetal development in the rabbit. F. exp. Zool. 156, 269.

Krishnan, R. S. \& Daniel, J. C., JR (1967) "Blastokinin": Inducer and regulator of blastocyst development in the rabbit uterus. Science, $\mathcal{N} . \Upsilon .158,490$.

MaLaren, A. \& Michie, D. (1959) Studies on the transfer of fertilized eggs to uterine foster mothers. II. The effect of transferring large numbers of eggs. F. exp. Biol. 36, 40 .

RUNNER, M. N. (1951) Differentiation of intrinsic and maternal factors governing intrauterine survival of mammalian young. F. exp. Zool. 116, 1.

SAto, A. (1959) Preliminary observations on artificial polyovulation and superfecundity in mature mice. Fap. F. Genet. 34, 226.

Senger, P. L., Lose, E. D. \& Ulberg, L. C. (1967) Reduced blood supply to the uterus as a cause for early embryonic death in the mouse. F. exp. Zool. 165, 337.

Vincent, G. K., Robison, O. W. \& UlbeRG, L. C. (1964) A technique for reciprocal embryo transfer in swine. 7. Anim. Sci. 23, 1084.

Whittingham, D. G. (1966) Critical phases in the cultivation of mouse ova in vitro. F. Cell Biol. 31, 123a.

Wrtson, E. D. \& Edwards, R. G. (1963) Parturition and increased litter size in mice after superovulation. F. Reprod. Fert. 5, 179. 